\title{
The Violence Against Children in Elbasan District, Albania
}

\author{
Darina Çoni ( Kacollja) \\ Lagjia nr 8 Rruga Aleksander Goga \& Mitrush Kuteli, Pallati "Turkeshi" Durres, Albania \\ darinakacollja@yahoo.com
}

\section{Doi:10.5901/mjss.2015.v6n2s1p172}

\begin{abstract}
This maltreatment against children occurs even inside their houses, from their family members and especially from their parents. Home at first glance seems calm and a harmonious place, but it is not that way because home is the place where conflicts happen, and they may even turn into violence. This situation is proved to be true even by the study realized in this district. In order to realize this study, two questionnaires were filled by 1200 persons included of different ages such as 13-23 years old and 18-60 years old. These questionnaires were delivered in these cities: Elbasan, Peqin, Gramsh and Librazhd. The factors that have an influence on the violence against children are the patriarchal mentality, the low economic state, communication, the usage of alcoholic drinks, etc. One of the main reasons of violence in the Elbasan district is Mediterranean patriarchal mentality, which is more widespread in the rural areas.
\end{abstract}

Keywords: Violence, children, patriarchal, violence, Elbasani district.

\section{Introduction}

This study is based on the violence against children in Elbasan Region and for its realization it is used the quantitative research method. There are used two different surveys with questions in order to help each other: the first survey is for people who are over 23 years old and the other survey for people up to 23 years old. These two surveys have in total 1200 respondents. The first survey which is for the people over 23 years old was distributed to be completed by 650 respondents, whereas the other survey was distributed to be completed by 550 respondents. The respondents that completed the surveys were randomly selected in the four districts of Elbasan according to the number of residents in each district. The study of violence against children is a bit difficult because its victims- children- are often reluctant or afraid to make known or express their cases of violence because they fear the negative reactions of their families, their teachers, and above all the fear of the society. The realization of this study is based on the use of priority of both sociological research methods: the method of qualitative research and the quantitative research method. A harmonious combination of both of them enables the study to be aligned as much as the social reality in the Elbasan Region. The study is realized in the Region of Elbasan because this city with a population of 295827 inhabitants is the third largest region after Tirana with 749365 inhabitants and after Fieri with 310331 inhabitans. It lies on both sides of Shkumbin River and it is situated in the middle of Albania so it is in the North and in the South. The uniqueness of this city is that it weaves the two main traditions of these two main areas. Moreover, during the years 1945-1990 Elbasan became one the main industrial regions in the Republic of Albania. In this district were built the cement industry and especially the Metallurgical Combine (complex). It provided the heavy industry with all its branches. It triggered the development of the city (Elbasani's Encyclopedia, 2003:294). In Librazhd, which is part of Elbasan District, was developed the industry of extraction and enrichment of iron-nickel and chromium, whereas in the District of Gramsh was developed the mechanical industry (Look at Elbasan Region, '14 without an edition year)

After the 1990s the industrial industries due to their outdated/old technology, due to their inability to reform them and to make them competitive in the market, failed to survive and thus they were closed. "This closure was accompanied by massive of unemployment, as for instance in 10 important and main industries of the city of Elbasan in 1990 were with 23.672 employees, but in 2003 there were employed only 2.275. From this perspective, Elbasan region in general and Elbasan district in particular, could be ranked among the regions with the most severe consequences of transition reforms (Elbasan Region, without an edition year, 14') 


\section{Literature Review}

These researches are based on the various sociological theories, starting from the formulation of the questions till the elaboration of this study. Sociological theories are wove and combined with each other by merging with the data obtained from the questionnaire and they form the structure of this study. Generally, if this combination is good then this study will be of a high quality. This According to Andrea Vargiu, the professor of methodology and techniques of sociological research: "This explains the continuity and the importance of theoretical dimension at any time of the research process and not only in the beginning or in the end" (2007:147).

In general, the sociological theories are widely spread and they are often too abstract for special searches and for this reason in the sociological searches we start from simple propositions in order to prove and verify them. Giovanni Delli Zotti, a lecturer in the University of Trieste, in his book titled "Introduzione alla ricerca sociale" (Introduction to Social Research), writes that "theories assert the existence of relation between social phenomena found in a higher level of the general principle, more often in an abstract way, and therefore a simple proposition should be followed: hypothesis preliminary interpret that will be subject to empirical testing" (2014: 45)

\section{Which is Considered as the Violence against Children?}

In 1999, Consolation of World Health Organization on Child Abuse Prevention processed the following definition: "Child Abuse or maltreatment constitutes all forms of physical and/or emotional ill-treatment, sexual abuse, neglect or negligent treatment or commercial or other exploitation, resulting in actual or potential harm to the child's health, survival, development or dignity in the context of a relationship of responsibility, trust or power". ( Tamo, A.; Karaj, Th., 2006:19).

This maltreatment against children occurs even inside their houses, from their family members and especially from their parents. Home at first glance seems calm and a harmonious place, but it is not that way because home is the place where conflicts happen, and they may even turn into violence. Or as it is said from the French philosopher Francoise Dolton: "The house where we live can turn into a battlefield hassles and squabbles. Parents criticize their children by telling them constantly that the house is not an inn. On their part, children, who are neater outside than inside, remind their parents that they are not domestic servants"(Dolton, F.; Dolton, C; Percheminier, C., 2013: 76).

\section{The Main Factors of this Violence}

Conflicts between generations are characteristics of all civilizations, from ancient time to the present day civilization. These conflicts that depend on various factors sometimes may turn into physical violence. As Hamit Beqja, a researcher, wrote: "As long as the human society exists and its core and unit are organically smaller and more structured, the family has intergenerational relations and there are always conflicting and problematic situations (Revista"Pajimi,, nr. 2.,1996:96 ). This clash between generations, which turns into violence, occurs because the new generation inclines to the new trends and its purpose is modern, progressive and it looks forward, but of course it may make mistakes. The old generation inclines to the old traditions and it looks with skepticism the new trends and new movements. This is also emphasized by the French philosopher, Francoise Dolton who quotes: "For what reasons the relations between adolescents and their parents are so complicated? Maybe, because in every generation the adolescent primarily decides and wants to experience the true values of humanity: generosity, absolutism, freedom, brotherhood" (Dolton, F.; Dolton, C; Percheminier, C., 2013: 82). Every generation tends to be new and original; it just needs to feel free and estimated. The new generation is not afraid to criticize, but it tries to change even the social institutions, when these institutions hamper the society's movement towards the new trends. As Francoise Dolton says: "Every generation of adolescents note that institutions which are established by adults in order to maintain the power have betrayed these values". Unfortunately, we can say that generation after generation these adolescents collide with these institutions (the same quote: 82). If there was not this new generation's movement toward the new and progressive trends, our life would not have any purpose and even the history would not have dynamism. The older generation has always tended to remember the youth days, when they even used to fight with the walls created by the society, and they still think that their generation differs a lot from the new generation. For this reason, the old generation is enforced to rely on the past, often on the outdated and by overstating it. However, Hanna Harend who is an American philosopher says: "The past never dies and it is not even the past. Furthermore, the past, that makes all the described way, does not pull us backward, but it pushes us forward, and unlikely what is expected, it is the future that pushes us toward the past" (1998:17). For these reasons the old generations inclines more toward the tradition. Sometimes it does not support the new trend, but it also fights against it. However, the movement toward the new and modern trends manages to attract the majority of the society, 
because only in this way the society moves forward. Moreover, the American philosopher states: "The end of a tradition does not necessarily mean that the traditional concepts have lost their power over people's minds. On the contrary, there are cases when this power with notional and obsolete categories becomes more tyrannical, when tradition loses its vivid strength and when people's memory starts to fade; it may even indicates its coercive strength only after it has come to an end and when people cannot turn against it" (1998:29). This clash between the old and new generations occurs in every society in various forms and ways. Sometimes, this clash between generations turns into violence, which affects more the children as the least indefensible part of the society. This violence in the Albanian society is increasing due to the severe socio economic problems that our society is going through. These problems will influence on the Albanian families and of course within the families of Elbasan County.

Generally speaking, the Albanian families and particularly the families of Elbasan County are facing serious problems, which are shaking its foundations, such as: divorce, prostitution, pedophilia, homosexuality, drugs, children with one parent, children born out of wedlock, children exploited savagely for illegal benefits, cohabitation, domestic violence etc.

Before 1990, divorce was a taboo, but after these years, it has begun to spread rapidly. Emigration, poverty and adultery were certain factors that accelerated this spread. Divorce was associated with a generation of children who grew up only with one parent and sometimes with children who grew up with grandmothers. This growth associates with trauma to the spiritual and physical conditions to children, because they feel excluded and inferior from the majority of children who grew with both parents. The family is the crux of the normal development of the society, but the destruction of this crux may be associated with various problems to the development of the society. In this way, we will have increased crime, trafficking, substance use etc. Psychologists have emphasized the connection between individuals' actions and the domestic violence incurred in their childhood.

Beside family problems, Albania is going through an economic-social transition which is associated with deeper problems. The society is divided in an irrational way; some people occupied lands, they built their houses without any permits and they became owners by forming a wave of discontent to the other part of population, especially to the former owners.

As the philosopher, Artan Fuga says: "In the eyes of the villagers of the city, the unsatisfied citizens did not have a real reason to complain for that situation. According to them, they used to complain because in the previous regime they were more privileged and they were losing the privileges in terms of democracy and market economy.

Being the "small bourgeois" of a socialist society and well protected by the former State, some people could not accept another policy of distribution of other assets and merits. Furthermore, in the newcomers' eyes, the social discontent among citizens was incomprehensible. They saw clearly that the economic situation and welfare among citizens were higher compared with rural areas. (2008:33) Only a small part of the society such as: businessmen, political leaders, anonymous people, were enriched in an immediate and rapid way and often accompanied by a shadow of doubt. The majority of the population lives near the poverty level and sometimes below this level. Workers, farmers, intellectuals who have worked hard during all their life, they have barely survived in this chaotic system.

This immediate and easy enrichment is fed by several opinions on public media and sometimes with an estimated argument for the capitalist system. This educates the new generation with the easiest way to become rich, but it causes the deformation of the real values of education to young people. According to the philosopher, Artan Fuga: "The transition period has requested a social and individual behavior somewhat determined by the rural and urban areas. The villager, the citizen and their families have to face a series of challenges with different nature: economic, material, physical and moral. In this new life, Albanians have originally entered with an opportunity and a life style which was already formed in previous periods. Therefore, new social relations, that were part of the transition period, required a rapid change of the whole values that guided the daily behavior of the villager and of the citizen as well as their families. In this way, social life is between moral traditions, which are more or less well maintained, and new values that are increasing gradually, created as a response of another style of living" (2008:269). Another reason is the social environment, which is very much "incriminated" because every day on TV there is daily news of murders, rapes, suicides, car accidents, theft and burglary, drug use etc. Almost the majority part of the Albanian society, especially the young people, support mostly those people who lead their life as "criminals"

Maria Calla, an Italian sociologist, emphasizes that: "A society that promotes or at least advertises violence through dissemination of violent images, violent films etc. may harm people with low self esteem, in order to affirm their image in the others' eyes (or themselves), so they might want to implement these abusive behaviors" (2011:59). Parents, who are situated in this pressure, fear that their children might fall prey to criminal activities. Having boys in this system it is a real problem. This idea is instilled in the psychology of our society, as boys are more liable to deviant behaviors because of their rebellious nature and the pressure exerted on them as the pillars of the house that are bound to keep 
their families financially. However, the situation for girls is not better, because having a daughter/girl is a problem too. During the times of anarchy, in Albania, the girls were considered more fragile and they used to be so much "protected" and for this reason girls started to be closed in their houses and they also were not allowed to go to school.

For these reasons parents were obliged to be very demanding and controllable to their children and in many cases they exceeded in various ways such as: imposing, set schedules for their free time activities, by controlling who they associate with, where do they go to drink coffee etc. This causes the growth of contradictions within families. These ideas were also emphasized by the Italian researcher Willy Pasini: "Many psychologists oppose this parental "inclusion", which is characterized by the total control over their children. Parents, who want to give their best to their children, risk of making their children unable to choose on their own $(2011,189)$. Nevertheless, the transition from childhood to adolescence increases the violence within families. An adolescent wants to develop his/her personality on his/her own. She/he does not want to be considered weak or small by the others and especially by his/her family members. He/she wants to be considered as an adult. On the other hand, parents have difficulties to accept that their children are grown up, because they have to accept that they are getting older in a time when they are still feeling young.

Adolescents start seeking for more independence in their actions and judgements. This is emphasized even by a researcher Hamit Beqja who says that: "In the way of developing their own personality adolescents face a lot of hurdles such as: socio-economic, ideological, cultural, ethical, traditional etc. Numerous practices and mechanisms of social life and more sustainable structured mentality and they can both play a conservative role or inert" (1995:287). Adolescence is not the only period of conflict within the family, but it is the period when relations between parents and adolescents change and evolve. During this phase of adolescence, parents have to reformulate the family's rules and they should not behave as if are dealing with a child. However, adolescents should not reject everything from their families. According to the Italian researcher Elena Besozzi: "The adolescence is not anymore characterized as the moment of the separation from the family and the crash with the parents, but like a period of transformation of the pre-existing ties in a different shape that implies a rethinking of the role of sons and of the parents figures. The transition ,then, is seen as regarding the entire family group, because it is a process in which parents and sons are renegotiating their relations on the base of the reciprocal expectations" (2003:89).

\section{Result of the Study for Elbasan Region}

All this economic-socio-psychological transition that has swept the whole Region of Elbasan and it is accompanied by a high number of domestic violence. The results from the data of the survey show that approximately $68.9 \%$ of the respondents claim that they have been violated in the family. This violence has lead to the physical violence against children and $21.3 \%$ of the respondents admit that they have experienced physical violence and about $43.3 \%$ of them claim that they have suffered from the psychological experience.

According to the data of the survey, the main violators against children are their own parents. These are the main people who contribute and take care for the children's growth and education, but they are even the ones who violate more their children. Moreover, based on the data of the survey it is the father who mostly violates children more and this is claimed by $41.6 \%$ of the respondents.

Even though the mother is the one who handles more with the children and she spends more time with them, but she is not the one who violates them. According to an Italian psychologist, Patrizia Romita "Fathers are often more violent than mothers, either when it come to physical or psychological violence, and this happens despite the fact that mothers are the one who spend more time and they take care for the children". (2007:31)

\section{Conclusion Remarks}

There are socio-economic problems such as poverty, unemployment, divorce, high rates of criminal cases that lead to the violence against children. However, even the patriarchal mentality that still exists and it is part of the society,is one of the main factors of this violence. Albania but even the Elbasan region has a history full of contradictions, sometimes showed with a war for existence and in this way there is a tendency for residents to fight with each-other. In general, there has not been a real tradition, in order to revalue the social and family tolerance in the Albanian society.

\section{References}

Delli Zotti Giovanni ; Introduction to social research, Edizioni Franco Angeli, Milano 2004

Elbasani: "Enciklopedi" Shtëpia Botuese "Rama Graf", Elbasan 2003 
Qarku Elbasan: Nxitja e zhvillimit rajonal nëpërmjet objektivave të mijëvjeçarit, Shtëpia Botuese "Pegi", Elbasan, 2002.

Andrea Vargiu "Metodologia e tecniche per la ricerca sociale" Franco Angeli 2007

Tamo Adem, Karaj Theodhori "Dhuna kunder femijeve ne Shqiperi" Tirane 2006

Dolton.Francoise, Dolton.Catherine, Percheminier.Colette; Fjalë për adoleshentët ose kompleksi i karavidhes, Shtëpia Botuese " Ombra GVG" Tiranë 2013.

Revista"Pajtimi,, nr 2. Viti i botimit 1996

Arendt, Hannah: Ndërmjet të shkuarës dhe të ardhmes, Shtëpia Botuese "Onufri", Tiranë, 1998.

Calla, Rose Marie: Conflitto e violonza nella coppia, Editore "Franco Angeli", Milano, 2011.

Beqja, Hamit: Edhe Ëngjëjlli, edhe djalli janë brenda te i gjalli, Shtëpia Botuese "Albinform", Tiranë, 1995.

Romito, Patrizia; Heshtje shurdhuese, Shtëpia Botuese "Dora D'Istria", Tiranë, 2007.

Pasini, Willy; Burrat që duam, Shtëpia Botuese "Belina", Tiranë, 2011

Besozzi.Elena; II Genere come risorsa comunicativa, Editor Franco Angeli, Milano 2003

Fuga, Artan: Briret e Dhise, Shtëpia Botuese "Ora", Tiranë, 2008.

Fuga, Artan:Media, politika, shoqëria : (1990-2000) : ikja nga kompleksi i Rozafës, Shtëpia Botuese "Dudaj", Tiranë, 2008 